\title{
KING, QUEEN, DAMA DE PAÇO AND ORIXÁS: SENSE AND MEANINGS OF THE CHARACTERS AND SYMBOLS WHO DANCE
}

\author{
I.B. FREIRE* e R. M. N. MEDEIROS \\ Universidade Federal do Rio Grande do Norte \\ isabfreire@hotmail.com*
}

Artigo submetido em novembro/2014 e aceito em novembro/2014

DOI: $10.15628 /$ holos.2014.2552

\section{ABSTRACT}

Once it discuss about a wide survey entitled "The symbolic language of Popular Dances", it we perform a clipping where we base this study. It is a deeping on the studies on folk dances which reflects mainly on the Maracatu and its manifestations, meanings and senses; thinking essentially in various kinds of art,
\end{abstract}

communication and language that can be understood and interpreted through their dance. Always considering how this whole cultural and symbolic universe can contribute to the knowledge of folk dances and their rootedness in Physical Education.

KEYWORDS: Popular Dances; Maracatu; Senses; Meanings and Physical Education. 


\section{REFLECTIONS ABOUT CULTURE, SYMBOLS AND ART IN FOLK DANCE}

Being able to understand the dance through the dancer led us (or LEDS) to think an individual that moves, expressing its own subjectivity, interiority and critical-creative potential. It's in dance's communication we can assimilate how much it's linked to the universe of the culture and the art entering, no doubt, individuals in the educational environment.

Dance communicates. With its language expressed by art, by culture, it communicates several knowledges that are and are enrolled in each gesture, each movement, each expression in those who dance, each garb, each spotlight that enhances the dancing bodies. Several scholars of the art, claim that dance encourage sensitivity, the discovery of the body itself, it contributes to the cultural and historical knowledge, brings people together, keeps traditions, allows the knowledge and recognition of symbols, enabling countless experiences and interpretations. Additionally, dancing allows different motor skills experiences and, lastly (or Finally), it's education. (Barreto, 2005; Marques, 2001; Tibúrcio e Porpino, 2005; Medeiros, 2010). We believe in folk dance as a way of recognizing thousands of meanings, using culture as a means of expression, reading and language and symbols as a way to express art.

Based on this thought, we consider fundamental, reflection of cultural meanings, symbolic and artistic trough folk dances, which according to Nóbrega (2000), are tangible texts which transcribes maks of culture; it's in the dancing body, in gesture and each movement it is carved its stories, its constitutions, beliefs and values, among many other aspects that high light culture. By culture we mean a complex and heterogeneous set of behaviors and common discursive modalities that determine a certain faculty of all members of the social group to produce certain signs, to identify them and interpret them the same way (Zumthor, 1993).

However, the culture doesn't occur in block, or it's closed. It, acutually, supports some heterogeneity. Thus, no culture is truly closed, and renews itself over time (Medeiros, 2010).

This consideration and reflection on culture can make it relevant to the Lara's assertion (2008), when she declares these dances express the needs of their indigenous communities, their aesthetic senses, the struggles and affirmations on the life of every gesture that performs as an identifier of the existing cultural plurality. Assuming, then, that the dances comprise a significant cultural element of humanity, artistically express the cultural, the legacy of a community, being expression of the people, their ways of being and living.

Dancing, individuals can establish their way of being, of living and relating to the world, renewing themselves, according to Lara (2008). A heterogeneous system supports differences even in terms of interpretations around several cultural elements, beliefs, dances, as far is the entire culture is renewed; but something always remains, it keeps and it's passed on, making culture's inscription something permanent. (Medeiros, 2010).

Recognizing the importance of culture, it's highlighted its intrinsic relationship with a symbolic universe, that are built and keeps numerous meanings transcribed by dancing bodies making sense to the word of Chevalier (2006), where he states that symbols are the key point, it constitutes the core of wondering life, where discloses the secrets of unconscious and drives to the most remote strings of action, opening the spirit to the infinite and the unknown. According to him, the world of symbols it's inside us, they live on us and we live in a world of symbols. 
Due to that brainwork on folk dances, culture inside each dancing gesture and the symbolic universe which permeates these artistic works; It's considered that the understanding of the beings who dances revealed in description of the riches that surround the Maracatu with its characters and symbols, it reflects, the various meanings that constitute the body of those who try this dance; expanding horizons and ratifying the artistic, cultural and symbolic universe involved as an essential source of knowledge.

Associating relevant considerations to the area of knowledge that circumvents the physical education and their conceptions of body, its view about culture, abusing and taking on the various concepts that are dazzled in folk dances as a way to claim all the thoughts that reflects the relevance, somewhat refreshing in this study. This is ratified in the speech of Medeiros (2010, p.119) when she says that:

"That consideration of art teaches much about the body and also about knowledge. It teaches that the bodies should not be considered homogeneous, since each individual assigns meanings to life, their existence from their experiences, from its opening to the world, his perception that opens and is similarly open to things. It teaches that the senses are part of every human act, making the individual experiences and weakening the rational consideration only in bodily processes." (Medeiros, 2010, p.119, translated by the author).

In this sense, it wonders, what are the meanings attached to the characters of maracatu? How are they revealed in the dances in question? How such sayings can help to broaden the knowledge of the folk dances in the context of physical education?

As a goal, some reflection about the symbols and characters of Maracatu is presented; besides exposing horizons of meaning to the knowledge of folk dances in the scope of physical education.

It settles down to relate a personal experience in the Field of physical education; throughout the course, concepts were built, discussions planted the learning and, from experience with the research, the seed sprouted, so the fruits resulted are valuable experiences in attempt to understand and supporting important principles, reflecting meanings about the body's understanding, movement, art, culture and education; These are concepts closely intertwined that dialogue with thoughts and attitudes which go hand in constant action in my life.

The development of this research provides essential information for the understanding of a sensitive eye to folk dances, once it dialogs with other experiences, with other cultural perspectives, structuring fortresses that communicate with various scopes that dived to can get in touch with certain reality. I believe that the wealth found in the world of popular dance becomes noble knowledge that is contagious to all who study and live the body, this body "Full of subjectivity and lying clipped by historicity, and this bodily condition that unfolds in theoretical and practical decisions of life and knowledge." Nobrega (2010, p.10, translated by the author).

In that sense, I understand being in existence the place where are printed directions, cause according to Nóbrega (2010, p. 11, translated by the author) "It's actually the body that allows us to feel and therefore perceive the world, objects, people. It is in fact the body that allows us to imagine, dream, wish, think, tell, know, choose." I consider essential to the knowledge the lived experience, I understand that this makes up myself, embraces me and guide me, because it's a result of my desires, choices and what it does mean for my existence. 
With this, I use as support the idea of Merleau-ponty $(1999$, p.3) once wisely says that "Everything we know of the world, even in science, I know from my own vision or an experience of the world without which the symbols of science would not say anything."

Therefore, I adopt the phenomenological approach of Merleau-Ponty, as a philosophical movement centered on life's experiences shared with other experiences, considering, this, as primary source of knowledge, as Nóbrega (1999) states "It's the attitude of engagement with the world of lived experience in order to understand it. This understanding is not a mental representation of the world, but instead engagement that allows reflection, interpretation and experience."

I identify in the phenomenological reflections, a method to our investigation, taking in consideration that the understanding of the universe of folk dances, immersed in the culture and symbols, from the various artistic and cultural contexts, it can amplify the phenomenological understanding, highlighting the thesis of sensitive body, open to different understandings and experiences, tied to a certain world, configured by existential meanings. In addition, we dialogue with hermeneutic phenomenology as a mode used to describe, understand and interpret the videos that according to Boll Weevil and Esposito (opp.cit31) questioning the phenomenon, search the relationship of people with the lived and communicated situations through human works described, sculpted, danced, etc.

Justifying dialogue with hermeneutics proposes an outline of the existing combination among the experienced universe of maracatu and a text, where, from hermeneutics, this universe will make text so we can understand it and interpret it, to essentially, take possession of the true sense and meaning which raises the maracatu. For that we support in Paul Ricoeur (2000, p.17, translated by the author), when he says that "Hermeneutics is the theory of the operations of understanding in its relation to interpretation of the texts." Thinking over these knowledges from videos of the Maracatu's Group "Nação Pernambuco" in its commemorative DVD of 21 years of history. Based on these analyzes we will launch our interpretations to the object of reference, it being symbolic language and the characters of the popular dances.

The Group of Maracatu "Nação de Pernambuco" it's a cultural group created and founded by Bernardino José on December 15, 1989, has recorded 04 albums and vast international curriculum with 10 tours across 3 continents, with shows in North America (USA), Asia (China) and Europe (Germany, Austria, Belgium, Spain, France, England, Italy, Netherlands, Portugal and Switzerland). The spectacles of "Nação de Pernambuco", on stage, have 32 artists on scene, among them wind instrumentalists, bassists, drummers, singers and dancers present various manifestations of brazilian northestern culture, particularly pernambucana, in an engaging and interactive manner choreographed by wonderful costumes, created by the artist João Neto. At the end, the entire cast comes out on parade with the public, showing the court of maracatu, one of the most beautiful, rich and ancient popular Brazilian culture, and also exclusive of the state of Pernambuco.

\section{CHARACTERS AND SYMBOLS WHO DANCES THE MARACATU}

We understand that symbolic meanings that permeate the popular dances while art created by the people, in their different cultural meanings, with numerous symbolic languages, 
revealed in the constitution of the various folk dances. In that sense, thinking of Maracatu, it's reflect upon these various aspects already discussed, understanding their symbolic and cultural richness.

The original miscegenation that contributed to the appearance of Maracatu consisted of a strong religious component and the dance was an important part in the rituals, better understanding in the elucidation of Santos (2002, p.38, translated by the author) "The role of dance in the rite it's to absorb the implicit doing in the religious context (...) these dances we observe that the movements aren't performed at random or simply as a response to the rhythm or music." The movements have a symbolic nature and are represented in a specific way.

Once enslaved, blacks coming to Brazil brought with them their entire religious tradition and their culture in order to continue the stay of instruments, movements and rituals, maintaining and recreating costumes, ethnic knowledge involving belief in ancestry, the power of speech, gesture and kinship, as stated in Munanga, 1988.

These elements came from Africa, before all the difficulties related to enslavement are reconstituted by taking new elements to which they were in contact; tha's how the Candomble "have arisen in an attempt to reconstruct this order as a central connection, solidarity, communion and maintenance of African values" (Lara, 2008, translated by the author). Candomblé, in its older meaning, it comes from a party, a cult of black religion that happened in the yards for celebration and appreciation of their Gods, their "orixás". These Orixás represent the essence of Camdomblé, since they are clearly life examples to be followed by its members, through their myths, wisdom, bravery and heroic attitude, according to Lara (2008). She also supports that the legends about the orixás showed their bravery, heroism, ambition, courage and, also errors, which would have taken them to to sacrifice their lives, turning into forces of nature, going to be a model for many people trust their fates to these gods. In these rituals that these facts are evoked.

The purity involving Camdomble highlights from its understanding of the development process of african-Brazilian religions, which many scholars associate and synthesize losses, adjustments, creation and re-Africanization process. We can highlight some orixás that make up this african-Brazilian regiliosity as Oxum, Xangô, lansã, Oxalá, Ogum e lemanjá.

Oxum "is god of fresh waters. Dancing with a copper's mirror (aberê) in one hand, he presents with gesticulations of such a vain woman who goes to bathe into rivers, which combs and looks in the mirror. Its waters are now calm and pleasant, sometimes turbulent and full of rapids. It moves necklaces and bracelets" (Lara, 2008, translated by the author).

Xangô "is god of storms, lightning, thunder, discharges of atmospheric eletricity (...). It presents itself as a young, strong, agile, sensual, domineering and proud, virile, racy, violent but vigilante, snatching on dance its its female devotees in a trance. Its main wives are: lansã, Oxum and Obá." (Cascudo, 1980, translated by the author). The symbol that represents him it's the "oxé", a double-sided ax.

"Known as the goddess of lightning, winds and storms is lansã. Mother of eguns (spirits of the dead) is the only orixá to have good relationship with death. Her sword is made of copper and symbolizes the the aggressive aspects of this orixá. She uses a badge made with the tail of animals to ward eguns. She dances with her arms outstretched as a way to release the fury of the elements (lightning, wind) and master the spirits of the dead. Her dance is performed basically in fast and 
very fast progress. Iansã's brave and warlike posture, it's combined with feminine sensuality in the dance" (Lara, 2008, translated by the author).

Oxalá is "considered the father of all. God of procreation, wise and counselor. He has two qualities: Oxalufã and Oxaguiã. The first is quite old. With his column curved by age, he dances with difficulty leaning on a staff called opaxorô. Oxaguiã is young, warrior, and his dancing is vivacious. The philosophy of Candomble reserve a proeminent place to the elderly, allowing them to express all thir wisdom" (Lara, 2008, translated by the author). Their insignia is the shepherd's crook with little bells.

Ogum "is the one who takes the lead, above the other and opens the way for those who follow. Myts lead to assign him to the violent and pioneer prehistoric man. First, he ivents weapons and tools made of stone, and, later, the iron ones. After being a Hunter and an expert on the secrets of the forest, becomes soldier and blacksmith. Seven to nine tools represents him" (Lara, 2008, translated by the author).

lemanjá is "considered the queen of the salt water, having enough prestige in Brazil. In many parties are thrown into sea scents, lipstick, flowers, mirrors and other objects in his honor. If lemanjá does not return them, the requests made to it will be realized. She's considered the mother of other orixás and dancing interpreting the movements of choppy waters. It seems to bring the sea to your feet and expand the space, alterning them, impulsively, inside to out. (..) It's related to femininity, beauty and motherhood. Its color is light blue." (Lara, 2008, translated by the author).

It's from this religious reference with symbolic nature that many cultural and artistic events were conducted, at the sight of it, we realized the value of this universe, its tiny expression trough words and his outsize consideration from the experiences we have had, "making clear that their perception it's very personal, and in turn depends on the culture of those who perceive it." Medeiros, 2010, translated by the author.

The symbols are present in communication and experience with/in the world, from the significant perceptions of the imagitative world lacing senses to the real world. Thus, we elucidated how revealing and expressive is the symbolism that surrounds the orixás and its constituent essence.

In african traditions, the melodious cult to the orixás presented and kept rits and myths that symbolized the intensity of manifestation of the sacred and its value in the lives of human beings. So we ratify that at the assertation of Lara (2008):

"The mythological revive drives to the understanding of reasons why certain things happen in the ritual, that way, yet, at present, leading, immediately, to religious precepts. Everything seems to be less obscure to know the ancient mythological situations and role models."

It was in this context that the Maracatu had enchancement, even with all indigenous and european influences, the striking and presente feature is in its dances it comes from African character, mantaining strong ties with Candomblé. The sacred tradition was based on the rituals performed in the "terreiros" (yards), where it evoked os "orixás" (deities) in order to bless the Maracatu, as to leave the carnival, the popular must request permission before the deities of the yards. 
Maracatu is a dance that representes the royal procession whose practices are reminicent arising of the parties of coronation of the black kings, elected and appointed in the institution of the king congo, wich relied on the protection of "white master" and the consent of the Catholic Church..

According to Lima (2003, p. 39) the institution of these coronations of the kings of Congo "was possessed of a distinctly Catholic character, despite evidence of the existence of elements of African religion."

Religious bonds that ensnare the understanding of Maracatu, contribute to realizing the reality surrounded by intense repression in the country, focusing on festive and carnival grounds to suppress the links with religiosity, particularly African. "The repression of Afro-Brazilian cults, especially in the First Republic and the Vargas period, as well as bleaching and transformations of black parties, conducts maracatus the tough times." Lara (2008, p.165, translated by the author)

In an attempt to find ways to survive, found the strategy of disassociate maracatu, documentary, of African religiosity, only gradually as stated Lima (2003), the values and ideals that would lead to a new look maracatus were being transformed even losing much of the discourse of Africanism to engage them in the discourse of authentic culture of Pernambuco.

The persecution and repression of Afro-Brazilian cults are striking to think about the demise of many nation-maracatus elements, because for many maracatu nation represented an extension of the "terreiros" of Candomblé.

Dancing in black culture, does not mean just run movements according to the rhythm played mean, before that, a moment of wisdom about their own culture, a meeting with your story - not just the story of submission, slave, but mainly the story of their gods, their kings and queens, its people, their ancestors. Therefore, considering the knowledge through artistic languages does not necessarily mean a reduction in ways that culture exist. Means fetching these aspects - as striking the african-Brazilian culture. - Their meanings, their values, their beliefs, their practices of knowledge "Alves (2006, 100 p.)

Given these statements, it is appropriate to reflect on the term maracatu, and dialogue with various scholars and their chances for that Andrade (1982) states that the term was originally from Guarani phonemes, for coming maraca - American Indian percussion instrument - and catu - good and beautiful in Tupi. Thus, the junction of the two terms form the term Maracatu. Already Fish (1980) diverges from this view, arguing that to corroborate this hypothesis with the rattle should have effectively participated in instrumental maracatu, a fact that is not located, even by the rhythmic nature of the instruments that make up the procession does not indicate involvement of the instrument Amerindian. "Thus says the word is of African origin, designating a dance practiced by members of the tribe of Bondos, near Luanda, at the time of Portuguese colonization" Lara (2011, translated by the author).

Lara (2011) argues that the procession of Maracatu is today in the streets, on the stump, the carnival and celebratory feasts, the sacred and profane space-time of society. The Pernambuco Carnival group hit the streets singing and dancing, sung by an orchestra consisting of only percussion instruments like the gongué, snare drum, bass drums and boxes of war, based on a singular musical grouping and does not contain any mutation; the characteristic music of Bantu origin maracatu is therefore translates all the historical aspect of the vigorous chorus that follows 
the procession. "In the old maracatu forms not perform the" corner-turn "and neither his singing is improvised, addressing timely topics. Rather, the songs have a particular rhythm, are turned into tradition and subjects are restricted to the rear. " (Guerra-peixe, 1980).

Contemplating the various dimensions that constitute the maracatu is to realize, among other characteristics, the mixture of majestic riches that give life meaning and accommodate important both for those who live this dance, fulfilling its cultural mix, and for those who enjoy the procession and realizes the senses that causes maracatu always considering all its religious, aesthetic and artistic cultural constitution.

For this, we envision the pieces dedicated brightness, meaning that the bargain charming character, which translate all the constituent aspects of maracatu, since its origin, since its clearly stated cultural tattoo, since all symbolic brands that enter mythical-religious functions from their gestures in dance is essentially meaningful and necessary for their full understanding. For Swap between the apprehension of the existence of symbols and characters in Maracatu is what we want to achieve that reflect the characters inhabit a world filled with intentionality, radiating axis essential to knowledge sources, making evident the various links that can be established between art and culture, the real and the virtual; understand that the characters come to life by reflecting on actors in humans built, rebuilt and designed with singularities of certain expressions, striking with regard to the existence, where we agree with (2013) on the definition of the characters, we believe that "character is a determinant of action, which is therefore a result of its existence and the way you present yourself. The character is a human (or humanized be anthropomorphized) recreated the scene by an artist-writer, and an artist-actor " it's this design that still ratify the Pallotine (2013) statement:

"The author, in creating a character and drew a diagram of a human being; fills it with the features that are necessary to it, gives you the colors that help exists, the forums have really. One truth is clear, fictional. It is not about having a character that is the actual copy of any one person, living, existing, well-known author. But to create a being of fiction, which satisfies the conditions of existence itself; that has consistency, internal logic, truthfulness. A being who could have been not necessarily be what is. " (Pallotine, 2013, p.25, translated by the author).

Thus, we wondered what we could consider the Maracatu characters? We agree with the thought of Girard (1980), stating that "the character of which we speak here is therefore originally a man bearing all the signs of the own transmitter-man, gesture and gestuality (or gesture which is also immobility) sound (...) mime (which may or may not be enhanced by lighting), wardrobe, props and even the scenery, because it defines a character never alone. "

Thus elucidate the King, Queen, Queen of the step (Rainha do Paço), and the Bahian Caboclos as examples of the main characters of Maracatu.

Elected as Queens and Kings of Congo were black political leaders, intermediaries between the colonial state and the power of women and men of African descent. The figures of the King and Queen stand out as it is in the pageant that sets the coronation, these individuals perform small movements of the sovereign, "making discrete evolutions with the sword in front of him while popular admired them respectfully" (Guerra-peixe,1980).

Cascudo (2002) recalls "a feature of the old maracatus, which is the big sun hat, red, running always, inseparably attached to the King, as the even typical element Arab in North Africa." 
It's called "Dama de Paço" "when she carries only a doll, a doll, and goes dancing and saluting with the doll, asking mutely money" (Cascudo, 2002).

According to Guerra-Peixe (1980), Maracatu gives some freedom to the "Dama do Paço" lady of step - "dancing with the doll, either linking it into the air, sometimes down, playing a dance more pronounced, but restricted to all the Bahian ladies (baianas) who dance the "folguedo" some kind of merriment for ladies. The "Dama do Paço" maid of dresses mostly red or pink as reference Yansã and yellow for Oshun. (reflect on the symbolism of colors)

The caboclos fulfill a work function, they make the protection of the King and Queen "leading bows and arrows, and some of them, axes and spears, dance otherwise: now put your hands on the ground and move your feet with extreme rapidity, for a side to the other; now get her back to the floor as losers in a fight; are now squatting, jumping in the same places; sometimes run from one side to the other, or moderately fast, in clear contrast with respect to directions and taking the time it takes walking; sometimes remain motionless, with his hand to his forehead, pretending to dazzle something away; now targeting the audience, pointing his warriors supplies, as if they expected "trap" some white" (Guerra-peixe,1980).

The "baianas" are characters that translate your movements into the dance of Xango, where mostly exalt movements of trunk, characteristic of african dance and its aesthetic forms (Medeiros, 2010).

According to Lara (2008), the "baianas" has the function festive, celebratory, stripped of sign, whether "rich" when they use sophisticated clothes or "poor" while dancing on strings and use chintz. Their gestures resemble the movements of the dances of deities, many turns, short steps, with mannerisms shoulders, hip's balance, bending arms and balanced.

When watching the DVD of the "Grupo Maracatu Nação Pernambuco", evidenced by the scene sung hymn of Pernambuco; its conspicuous relationship exists in the details of each character uniqueness, the energy of true strength, joy, pride revealed in the cradle of Pernambuco's popular culture, reproduced mainly by similar movements, though expressed differently, leading to think of cultural expression and historical, translated in moving bodies that climactic and full of riches dance.

Thus, we can confirm that the "Dama do Paço" -Lady of the Step - , in this scene the anthem of Pernambuco where she proposes a unique vibrancy, even if the movements of the arms and legs are the same as the other characters, she has a different intensity and intention to perform the movements with the doll, with her gyrations driven by strong drumming, we realize the doll as an extension of the lady's, a unique relationship, bringing to the stage shine existing relations between the symbols and characters Maracatu. Thus, evoke as significant the reflection of the Maracatu express and proposes through the details of the motion, the intent of each body tied to their historical and cultural character principles, real way for anyone who lives, studies and enjoys the Maracatu.

As in many popular demonstrations, Maracatu has its existence marked by sacred context, vigorous face and expressed mainly by the figure of Calunga. According to Lara (2008, p.134):

The expression calunga assumes several meanings according to various scholars investigated by Andrade (1982), such as: planta rutácea, camundongo, boneco ou indivíduo vadio e ratoneiro, negro, senhor (chefe), mar (em angolense), admiração, pasmo, morte, terra sem mal 
dos ameríndios, boneco, atributo religioso e político, rapariguinha, filhinha (calumba), catita (camundongo e diminutivo de catarina, personagem do bumba-meu-boi ou boneco de feitiçaria em Pernambuco), maneca ou cabocla. The author believes that calunga whould be all that and more, adding the idea of idol, spell, object mystical excitement, political-religious symbol of godkings. Not a god, but na object that provides entry into trance.

However, for the popular of Maracatu, the Calunga is not considered a character is commonly seen as mythical symbol in figure of egum (ancestor - king or queen) or orixás of Candomblé, subject to purification ritual for the exits during the carnival. Certainly is one of the intriguing aspects, by being both sacred object and living presence (or ancestral deities - orixás) that everyone should respect.

Calunga represents the root of African ancestry, and to it are enshrined the strongest songs; dance with the doll has its relevance especially his religious character, it is a lifeline to the headquarters of Maracatu, at times when the group goes out. According to Guerra-peixe (1980, p.42):

"The dance is as follows: the "dama do paço" deliver the doll to the queen; this passes it to the nearest "baiana", which in turn yields to the other. Thus, the doll goes through the hands of all "baianas", fitting each dance a little with her. After the round, the last returns to the Queen, who turns the table (sort of altar) and put in place."

\section{KNOWLEDGE BUILT TO PHYSICAL EDUCATION}

We belive that with its glorious and charming character the Maracatu, full of elements that convey meaning within a society transfixed by all religious and cultural thread that enters the symbolic world, affects all who live, who attends and who studies. Thus, the multiple meanings that we attribute to the King and Queen, covered by a dazzlingly colorful sun hat, can - in effect articulating cultural meanings, as well as the doll (Calunga) shatters us with its religious significance; thus revealing that the characters of maracatu communicates various knowledges that are registered and are in every gesture, every movement, every expression of those who dance in each garment, since, besides affecting and shake, unmoved, impress, sensitize and touch, they constitute our world, the world of being, the world of the story lived by the characters and creatures dancing, weaving numerous meanings and significances. We believe that knowledge can be added to studies that link the cultural and symbolic languages as sources of knowledge and education. Thought education beyond the formal spaces, but also present in the space of art and the specific space of the popular dances.

Thinking especially of the various contributions to the field of physical education knowledge, it is important to make it relevant the research that shows various forms of the body reflection, making use of dance. Even with a biased eye and with a simplistic perception, it is necessary that physical education expand their conceptual horizons that outline the scope of dance, this knowledge rich and full of unimaginable elements that are and should be shared, bringing to reality the area a different look for the body and movement, perceiving it not only in its visible aspect, but also on your sensitive aspect, considering dance as art, ratifying the true sense proposed by lived experience, whether in folk dance, which brings its history, its tradition, tattooed on body language conveyed this research through the Maracatu, sung by symbols and 
characters in an universe that dances. In addition, understanding dance as a knowledge that appears unfinished and open to various interpretations, we confirm that the dance is education, in the sense of thinking about education beyond education and acquisition of knowledge, an education that fosters the fascinating experience of creation in a personalized way.

\section{REFERENCES}

1. ALVES, T. A. Heranças de corpos brincantes - Saberes da corporeidade em danças afrobrasileiras. Editora da UFRN. (2006).

2. ANDRADE, M. Danças dramáticas do Brasil. São Paulo: Itatiaia. (1982).

3. CASCUDO, L. C. Folclore do Brasil: pesquisas e notas. Natal: Fundação José Augusto. (1980). . Dicionário do folclore brasileiro. Belo Horizonte; Itatiaia; São Paulo: Editora da Universidade de São Paulo. . História dos nossos gestos.' São Paulo: Global. (2003).

4. CHEVALIER, J. Dicionário de símbolos: mitos, sonhos, costumes, gestos, formas, figuras, cores, números. Rio de Janeiro: José Olympio. (2006).

5. ELIADE, M. Mito do eterno retorno: cosmo e história. São Paulo: Mercuryo. (1992).

6. ESPOSITO, V.H. e BICUDO, M.A.V. (Orgs.). A pesquisa qualitativa em educação: um enfoque fenomenológico. Piracicaba: Editora UNIMEP. (1994).

7. GIRARD, G. O universo do teatro. Coimbra: Almedina. (1980).

8. GURGEL, D. Espaço e tempo do folclore potiguar: folclore geral: folclore brasileiro. Natal/RN: Departamento Estadual de Imprensa. (2001).

9. LARA, M. L. As Danças do Candomblé Corpo, rito e educação. Maringá. (2008).

10. LARA, M. L. Corpo, sentido Ético-Estético e cultura popular. Maringá: Eduem. (2011).

11. LIMA, I. M. F. Maracatu-nação: ressignificando velhas histórias. Recife: UFPE. Monografia (graduação em História) - Centro de Filosofia e Ciências Humanas, Departamento de História, Universidade Federal de Pernambuco. (2003).

12. MEDEIROS, R. M. N. Uma educação tecida no corpo. São Paulo: Annablume. (2010).

13. MERLEAU-PONTY, M. Fenomenologia da Percepção. São Paulo: Martins Fontes. (1999)

14. MUNANGA, K. Negritude. Usos e Sentidos. 2o edição. São Paulo: Ática, 1988.

15. NÓBREGA, T. P. Dançar para não esquecer quem somos: por uma estética da dança popular. Texto apresentado durante mesa-redonda no II Congresso Latino Americano e III Congresso Brasileiro de Educação Motora. Natal/RN, 2000.

16. NÓBREGA, T. P; VIANA, Raimundo N. A. Espaço e tempo das danças populares: uma abordagem coreológica in: Revista do Paidéia: Revista Brasileira de ensino de arte e educação física. Natal: UFRN/PAIDEIA/MEC.

17. NÓBREGA, T. P. Para uma teoria da corporeidade: Um diálogo com Merleau-Ponty e o pensamento complexo. Tese (Doutorado em Educação - UNIMEP), Piracicaba, SP. (1999).

18. NÓBREGA, T. P. Uma fenomenologia do corpo. São Paulo: Editora Livraria da Física. (2010).

19. PALLOTTINI, R. Dramaturgia: A construção da personagem. 2edição. São Paulo: Perspectiva. 
(2013).

20. PEIXE, G. Maracatus do Recife. São Paulo, Rio de Janeiro: Irmãos Vitali. (1980).

21. RICOEUR, P. Interpretação e Ideologias - organização, tradução e apresentação de Hilton Japiassu. Rio de Janeiro, F. Alves, 30 edição. (1988).

22. SANTOS, I. F. Corpo e Ancestralidade: uma proposta pluricultural de dança-arte-educação. Salvador: EDUFBA. (2002).

23. ZUMTHOR, P. A letra e a voz: a literatura medieval. São Paulo: Companhia das Letras.(1993). 